\title{
Improvising Freedom in Prison
}

\section{Nayanee Basu}

\section{Introduction}

This paper draws on fieldwork that was undertaken for my doctoral research in sociology. The underpinning research has been reinforced with subsequent field updates. I developed an ethnographic study of healing through dance at three different kinds of sites in Kolkata, the state capital of West Bengal, India. Correctional Homes of the state where art therapy had been introduced form one of my fields and the focus of this paper. Between 2005 and 2010 dance and other cultural activities were introduced for the wellbeing of the prison inmates by B.D. Sharma, the Inspector General of West Bengal Correctional Services (Police), in keeping with the new legislation that transformed the jails of the state into Correctional Homes. This paper is based mainly on the ethnographic account of the experiences of Sharma, Alokananda Roy (the well-known classical dancer involved in the process) and Nigel Akkara, a beneficiary of the process.

I take improvisation as a lens to view the interventions of both dancer and administrator as a case study of administrative reform and social activism through art practice. I understand it in a practice-based context, not as an abstract concept gleaned out of the flow. I draw out the implications of their efforts for the institution of prison and the society at large. Improvisation in this project works at a number of levels. The subject and content of the dance dramas, while built around classical themes of good and evil, the rule bound versus the unpredictable, and liberation, lend themselves to artistic improvisatory interpretations. These are not just performed but lived in the experiences of prisoners and guards, as well as through civic processes as these slowly bend in response to the new energy. The dynamic gradually provokes change, which is reflected in the attitudes and practices of the prisoners themselves. There is a transmutation in the individual prisoner's levels of interest, self reliance, respect, and self organisation as well as in the overall policy and rules of penal organisation in the region of West Bengal. Artistic improvisation opens up doubt in this case study in the social realm, challenging the instituted physical and emotional separation between prisoners and non-prisoners in quite practical, considered ways, altering but not dissolving the system.

Hallam and Ingold's perspective on improvisation forms the conceptual starting point of this paper. As social anthropologists, they explore creativity as cultural improvisation. In their articulation, life is fundamentally unscripted; people have to improvise their way through it. The world, rather than being ready-made, is crescent. They identify four characteristics of improvisation: it is generative in the sense that it gives rise to the phenomenal forms of culture as experienced by those who live by them or in accord with them. Improvisation is not conditional upon judgments of novelty. It is relational in that it is continually attuned and responsive to the performances of others. Therefore, it does not pit the individual against either nature or society. Improvisation is temporal, implying that it embodies a certain duration, inhering in the onward propulsion of life rather than being broken off, as a new present, from a past that is already over. Finally, improvisation is the way we work, not only in the ordinary conduct of our everyday lives, but also in our studied reflections on these lives in fields of art, literature and science. The creativity of our imaginative reflections is inseparable from our performative engagements with the materials that surround us (Hallam and Ingold 1-15).

\section{Art Reformation Therapy: an excerpt from the documentary Metamorphosis}

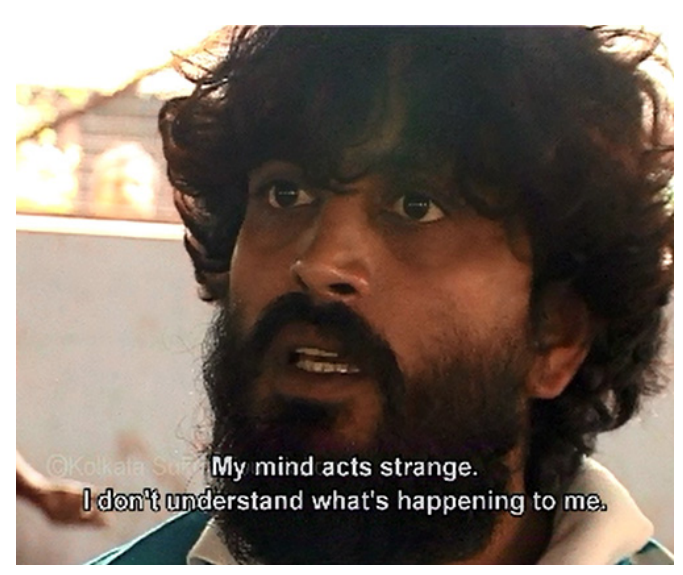

Visual material accompanies this article to provide a real sense of the context of the Presidency Correctional Home and the interventions that brought about change. However, it should be noted that this material is a clip extracted from a documentary called Metamorphosis, directed by Abhijit Dasgupta. He has made a series of documentaries on the culture therapy process in West Bengal, some of which have won a number of international awards (e.g., The Jail [2009]). The clip is the property of the Kolkata Sukriti Foundation. It is an independent piece of art and not ethnographic material. It is relevant to this article in that it emerges out of the context of current West Bengal, India, where institutions and personhood are seen, understood, and experienced differently from those of North America or Western Europe. The film clip should be viewed with this borne in mind. The inmates have spoken, sang, 
and recited poetry for this documentary. None of them were forced into participating. These people are not under trial but are convicts. Their crimes have been proven. None of them had a problem with the documentary, as their participation was voluntary. It has been shown within the correctional homes.

\section{Institutional Reform: Improvisational Opportunity?}

In 1992 the West Bengal State Legislative Assembly passed the "West Bengal Correctional Services Act," which repealed the former colonial law based on retributive principles in West Bengal, India. The new Act promises:

$4[\ldots]$ (b) to give correctional treatment to the prisoners in custody so as to efface from their mind the evil influence of anti-social ways of life and rehabilitate them in the society as good and useful citizens;

(c) to adopt measures whereby a prisoner confined therein may not fall prey to the depriving mental attitude which may make him believe that he is lost to the society and it is his fate to pass the rest of his life as a social outcaste;

[...] (g) to take measures for mental and moral uplift of the prisoners and to provide them with educational and other facilities for upgrading their qualities, character and mental attitude;

[...] (j) to enforce discipline among its officers and other employees and the prisoners in accordance with the provisions of this Act and the rules made thereunder. (494-5)

Sharma took charge as the Inspector General (and subsequently as the Additional Director General) of Correctional Services, West Bengal Police, on 7 November 2005. The new law had been "implemented officially" on 14 April 2000. Even after five years of such "official implementation," the administrative rules had not been framed. Such a situation of the characteristic "status quo" is not unheard of in the Indian police bureaucracy, which could be significantly prolonged as it had been before. Dissatisfaction greeted him at every turn. The staff complained of inferior status and pay, as well as a lack of security. The staff unions flexed their muscle on most issues. The prisoners complained about ill-treatment meted out to them within the correctional homes, delays in their trials, bad living conditions, indignities of prison life, lack of communication facilities for connecting with their families, and unequal treatment of rich and poor prisoners by the junior level staff. Sharma began to explore the possibilities beyond these systemic letdowns. In a manner quite uncharacteristic of a bureaucrat's office, rules began to be formulated. He explains: ${ }^{1}$

Whatever ideas I tried, including culture therapy or education or various other things_telephones ${ }^{2}[\ldots]-$ I did just out of my own conviction. And after trying out their success, after being convinced about their success, then I drafted. It took me almost two years to draft the-you know it was a matter of shame that we did not have the rules yet and it was constantly eating into my-normally what happens is you make the rules and then you implement them. Here what happened is I did things first and then I made the rules and I submitted the set of rules to the state government. I think it was in 2010 December. Then in the session of June 2011 they did not pass it. And then the government changed. And I got transferred, the new government came and the rules are yet to be made, by the way! (27 August 2012)

Sharma responded to the contingencies without getting overwhelmed by the constraints, generatively, with a very good grasp of the circumstances. He tried out various new modules like theatre, dance, painting, sculpture, recitation, music, sports, a safe telephone-facility, self-help funds, and a prisoners' council within Correctional Homes in the state. Taking the rehabilitative ethos of the new Act as the benchmark, he continued to improvise and generate suitable administrative programmes, most of which were the first of their kind in Indian prisons. Instead of taking the typical route of fulfilling the bureaucratic formality of drafting the rules of administration mechanically, Sharma experimented with what worked for the overall wellbeing of the correctional homes.

Narrating how it all came about, he mentions that many years ago he was posted in the district of Murshidabad in central West Bengal. A lover of theatre, he would frequent performances there. Among those he remembered were the quality productions of director Pradip Bhattacharya at the Berhampore Repertory Theatre. While touring the Berhampore Correctional Home (BCCH) in July 2006, Sharma invited Bhattacharya and requested him to put on a cultural show inside the jail for the entertainment of the prisoners. A play on rural literacy was staged, prior to which a few of the prisoners sang songs and recited poetry. Watching the function, Sharma was struck with the idea of asking Bhattacharya to initiate a theatre workshop involving the prisoners with the goal of a performance in the end inside the jail. Bhattacharya readily agreed. 
Sharma's appreciation of Bhatacharya's work in theatre led to their collaboration. Attempting to understand experiential knowledge and improvisation, Douglas and Coessens emphasize the importance of such collaboration through their own partnerships with artists. They opine, "In engaging with their work, we become open to new experience, responding from our own centre, modifying through our creative imagination what happens next. This is different from imaging knowledge as extracted and applied. It is knowledge that has to be lived" ("Experiential Knowledge" 24).

Improvisation thus evidences a complex interaction that is both relational and generative, the one building upon the other. Certitude of skill also plays a critical role here, as Sharma was confident of Bhattacharya's proficiency. He could then imagine the positive experience theatre would foster in the prisoners' lives. Each worked from his own centre and individuality that started to create a possibility of change.

Tasher Desh (Kingdom of Cards), a play composed by Rabindranath Tagore, revolves around the theme of breaking free of mechanical, limiting rules to embrace life in its unpredictability and freedom. A prince bids farewell to his life of royal luxury to embark on a journey to unknown lands across the seven seas. He is shipwrecked on the shores of the Kingdom of Cards where people take every step in life as per set rules. His arrival and tete-a-tete with the locals lead to an overturning of the system. Even the queen volunteers to be exiled from the mechanical, rule-bound court and is finally followed by the king who doesn't want to be left behind and all alone. The old system of fitting life into set rules thus crumbles, which completes the revolution. The prince's risky voyage leads to upheaval, change, and yet fulfilment.

In November 2006, Tasher Desh (Kingdom of Cards) was performed by 24 prisoners (18 men and six women). Sharma reminisces that the in-house show of one hour and 15 minutes left everyone speechless. He remarks:

What a superb rendition of such a subtle play by these prisoners, [the] majority of whom are barely educated! I suddenly found myself almost in tears, thinking, my goodness, such a programme if they can take it out because of the sheer quality and rendition! I felt-an inner voice told me if you can't take it out and showcase it before the general society, it would be a crime against humanity. And while addressing them I found myself saying that I will try to take this programme out, without thinking how this was going to be. There was a huge applause-I spoke like a fool without realizing the implications. It came out in the press. I was now determined-there was no instance, no example, no precedent or history of such a step. Finally when I raised the subject with the jail minister, who had been very appreciative of the theatre workshop, he said, "You have lost your head!" I did not give up and kept on telling him and he went on rejecting it outright. (27 August 2012)

A satire on the futility of regimentation, Tasher Desh represents important self-reflective content. Tagore's creation born out of his own experiential knowledge of working his way out of existential constraints seems to have struck a chord with the prisoners. ${ }^{3}$ The emotions expressed in the lines they delivered and the predicament of the characters they embodied echoed their own conditions of having to lead a mechanical and regimented life as inmates. The monotonous routine of most prisons is out of beat with an individual prisoner's life-rhythm. Such an activity provided, perhaps for the first time, a legitimate space within the prison to reflect upon the need to break free of such a life and accept that emotion. The prisoners' unfamiliarity with Tagorean literature and their lack of cultural capital were compensated by their ability to identify with the characters they played and their intuitive understanding of the characters' circumstances. Henri Bergson's concept of intuition resembles this process of identification that the prisoners underwent:

Consider [...] a character whose adventures are related to me in a novel. The author may multiply the traits of his hero's character, may make him speak and act as he pleases, but all this can never be equivalent to the simple and indivisible feeling which I should experience if I were able for an instant to identify myself with the person of the hero himself. Out of that indivisible feeling, as from a spring, all words, gestures, and actions of the man would appear to me to flow naturally. [...] By intuition is meant the kind of intellectual sympathy by which one places oneself within an object in order to coincide with what is unique in it and consequently inexpressible. (22-3)

Realizing the value of this soulful participation, Sharma felt the need to honour it and spoke spontaneously. He strove for the impossible without any idea of how it was going to be or what structural implications would be read into his actions by the political and bureaucratic authorities in a post-colonial, developing society. Amazed at the creative potential of the prisoners that lay buried under their "anti-social" identities, Sharma wanted to set this energy free-let it take wings of its own. Administrative "reform" for a post-colonial society like India has mixed connotations. The present institutions of governance are not exactly indigenous in their genesis. The question of control in re- 
form(ulation) hovers undeniably and uncomfortably in the horizon. Sharma's actions at this stage seem to be generated from and generative of a quest for freedom of expression without any concrete strategy for controlling the proceedings to make lasting institutions out of them. He does not endeavour to predict the probability of its success or failure; instead, he simply chooses to take the risk of trusting his imagination, and perseveres.

\section{Improvisation: A Critical Counterpoint to a Dominant Way of Doing Things}

Returning to Kolkata, Sharma kept turning the idea of having the prisoners perform outside the prison confines over in his mind. On International Women's Day the next year, a small function was held inside the Presidency Correctional Home in Kolkata in keeping with the stipulations on recreation in the new Act, and Alokananda Roy, a dancer of international repute, was invited to grace the occasion. ${ }^{4}$ Describing the chance interaction at the Presidency Jail, Roy says:

Actually I didn't have any plans as such [...] I went as a guest by the invitation of Sharma [...] And he just casually asked me if I could do something, think of something with the prisoners, because now it was a correctional home and they are using different methods, ideology to help. I said "of course I can" without thinking anything. I started talking to the women there; they were very excited they were going to dance because they have a very monotonous life. [...] And when I was coming out from the women's ward I saw these young boys walking aimlessly without anything to look forward to-aimless, and their bored monotonous life — I just spontaneously asked Sharma, "Can I also work with the boys?" He said, "If you want to, if you have the courage." I said, "Of course I have the courage." (28 May 2010)

The Presidency Correctional Home is one of the oldest prisons of Kolkata, incarcerating a large number of criminals and those under trial for serious offences such as murder, rape, drug-peddling, terrorism against the State, and domestic crimes. Roy's decision to engage the prisoners in dance required "courage" from any person having a middle-class upbringing who lacks training and experience in dealing with criminals. In her spontaneous proposal to work with male prisoners, one can read a critical counterpoint to a dominant way of doing things. Improvisation here involves an appraisal of possibility in a given situation-Roy's openness to taking the road less travelled-and then actualizing it. She emphasizes the spontaneous nature of her decision against the backdrop of a monotonous prisonlife that renders even the youth bored and aimless. Improvisation is not equated with spontaneity here, though I do think every improvisatory act begins from a decision, a part of which is unknown even to the one improvising. In her response, the generative quality of improvisation, unfettered by an anxiety of the resulting form, is evident.

She attributes the ease with which a rapport developed between her and the prisoners to the essentially unplanned nature of their initial encounter. She recounts that day:

Believe me when I am asked that how did you feel the first day [...] I never thought of them as something different, they are all my son's age-most of them, I saw my son in each one of them in the sense that they are also somebody's son, somebody's father, somebody's husband, so that's how I saw them right from the beginning, because actually I didn't go with any plans maybe that's why the feeling was different from if I went with some work in mind. It was a very emotional beginning when I started on the $25^{\text {th }}$ of March $2007-$ it's still an ongoing thing. (28 May 2010)

A strong indication of the relational quality is apparent in her approach to the inmates. She speaks of them as though they are her own family, seeing each of them as her own son, and she uses that affinity to communicate how they remain connected to the human community outside the prison walls. This spontaneous, emotional connection marks the beginning of their bond.

Meanwhile, Sharma's desire to take the prisoners' performance outside the confines of the prisons grew steadily. After groping in the dark for several weeks, he says,

Suddenly it occurred to me, "Why not parole?" 5 discussed with senior officials who, though not very sure initially, nevertheless agreed that it was not implausible. Their initial reservation stemmed from the lack of any such precedence. Once again I approached the minister, who agreed on this but was still not convinced about taking such a huge risk, as most of the prisoners acting were life-convicts. ...home secretary etc. nobody was for it. But somehow I accessed the chief minister. Buddhababu [Buddhadeb Bhattacharya] was thrilled-he said, "This is a great idea-are there no legal complications-can you do that?" I said, "Yes, I have been given powers of parole. My idea is if parole can be used for going home why not for an activity 
like this? [As the I.G.] I would take them out on parole they will perform and go back. There is nothing legally complicated about it." (17 November 2010)

Parole was an experimental step Sharma took that may or may not have worked. On the topic of improvisation and experimentation, Douglas and Coessens observe that "[w]hile improvisation in life is part of a situation that is contingent that we haven't chosen, experimentation is part of an explicit position and choice" (Douglas and Coessens, "Improvisation and Experimentation"). Sharma's deliberate method accurately represents their position. Convinced now to push forward with determinacy, he conveyed his idea to the highest authority in the state, whose doubts were overcome by Sharma's certitude regarding the form of administrative improvisation that he proposed. The trepidations of possible failure and contingency were dissolved by the improviser's certitude of what he could do from his position. The risk-factor in taking prisoners out for performance was undeniable; however, Sharma was ready to handle it.

\section{Freedom, Constraint, and Improvisation: Somewhere Within the Pull and Push...}

Though the permission from the Chief Minister's office infused new energy into the process, it was hardly smooth sailing. Constraints ranged from macro realities like institutional practices and malpractices to the inmates' lack of personal self-belief. Infrastructural facilitation had to be improvised through such obstacles, negotiating freedom in different ways. For instance, in 2006 Sharma granted access to NGOs, celebrities, judges, and magistrates with the convention of the "First-State level Dialogue with Social Organizations." The staff felt threatened because earlier they had absolute control with unquestioned authority over the affairs inside the four walls. They habitually opposed the entry of the NGOs on grounds of security. With the entry of leaders and activists into the institution, the rampant corruption and malpractices of centuries (indicative of staff involvement) would come under scrutiny. Sharma reveals, "we roped in some members of the staff-that was very important because there was a lot of resistance on the part of the staff" (17 November 2010). There is an age-old stipulation in the "West Bengal Jail Rules" (vide Rule 949) with the following provision: "no female prisoner shall, on any consideration, be allowed to leave the female enclosure of the jail except for release, transfer or attendance at Court or under the orders of the Superintendent for any special purpose" (284). Taking a conservative, restrictive interpretation of this, prison officers and the staff union opposed the joint participation of men and women in rehearsals. Verbal orders given by Sharma were flouted repeatedly. Finally, he had to institute a written order to allow women inmates to rehearse with the men since tolerating such discrimination against women inmates, which deprived them of healing and developmental opportunities, was against the stated functions of the new Act as well as his personal ethics. The rule thus had to be changed. As a security measure, the female guards now accompany the women during their participation in such activities outside the female enclosure. The rehearsals went on despite these petty obstructions from the staff union. An established rule was thus changed, not through legislature, but through the administrator's improvisatory facilitation.

When Sharma first floated the idea of a theatre workshop inside the prison, the prisoners were not very keen.

The inmates wouldn't believe me-they thought it was a joke and they will not at all agree with the idea and they said "no this we will not do. We can't perform." There was a complete lack of self-belief, selfconfidence, on the part of the inmates. They thought that probably it's a joke on my part. But then gradually when things started happening, slowly and gradually they felt more and more emboldened. ${ }^{6}$ (17 November 2010)

On 17 May 2007, in the presence of the Chief Minister, Tasher Desh was performed as part of the $146^{\text {th }}$ anniversary celebrations of the birth of Rabindranath Tagore at Rabindra Sadan ${ }^{7}$ in Kolkata. He reminisces that the quality of the performance was matched only by the thunderous applause that shook the auditorium repeatedly.

\section{Perception and Improvisation: To See or Not to See ... The Choice is Open}

Meanwhile, Alokananda Roy was now a regular at the Presidency Correctional Home. Roy's lack of so-called official training in dealing with prisoners became her strong point in that her perception was free from prejudice. Many socalled "trained" personnel fail to treat prisoners properly; unlike Roy, they do not acknowledge their humanness. She, however, could connect readily to the persons whom she inspired to dance. Her perception and acceptance of them as persons having normal emotional requirements, such as the need to belong to a family, led to a spontaneous, emotional bonding. The strong relational quality of her improvisatory praxis rested on an open-ended, social engagement with the prison community. Situations arose and her responses to them were the same as her responses would have been to any situation outside the prison walls. On her experiences as a "visitor" in the jail, Roy says that she was unaware, initially, of the way things were inside. The prisoners perhaps took her to be from some 
NGO who has come to make money. This assumption changed when an incident occurred one day. It was very hot and one of the boys fell ill. She suggested giving him some water. They gave him water to drink and that didn't have much of an effect on his condition. Then, she took some water and patted it all over his head, his neck, behind the ears, and on his face; she then stroked his head, trying to make him feel better. Amazed, the boy just kept looking at Roy. She felt that he wished to say something but couldn't somehow utter anything. Then he expressed his wish to dance, but she asked him to just sit next to her (as he was ill) while she conducted the class. Till then she had no idea that the prisoners were treated almost like untouchables by the outside world. In this context, her gesture was unique. Roy reminisces, "the next day he wrote a note to me-it said I don't remember my mother but now when I close my eyes and I think of my mother I see your face-you really love us, don't you?" (28 May 2010).

Comparing dance-as a recreational activity - with sports, Roy points out that the latter is competitive while dance involves bringing one's body, mind, and soul into harmony with music and rhythm. According to her, when one feels good, there is a change in his or her attitude and perception of things. Some things that are fraught with negativity gradually become positive if one has harmony within. Her understanding is not far from that of André Leroi-Gourhan, who observes that rhythms are "the creators of forms" (309). In discussing Japanese calligraphy and KampiKolam, Ingold notes that both are learned and remembered as rhythmic gestures; their "rhythmicity" weaves their traces into recognizable forms (50). The therapeutic quality in recreational dance lies in the happiness that is felt when one dances to the music and its rhythm. Roy is not formally trained in dance movement therapy; however, she draws from her in-depth, felt knowledge of the art form and her life experience. Empathy constitutes a major ingredient in her improvisation: "You know I didn't do it consciously. I know how dance has helped me in my life. I have had a lot of ups and downs, lot of downs. I have gone through very difficult times but dance was something that has sustained me and always helped me to bounce back" (28 May 2010). Her subjective experience of dancing-yielding an awareness of overall wellbeing -is complemented with a strong belief that there are few who do not take to dance. One might not be a dancer, but the joy of moving to rhythm and music is present in every person. Roy's notion of health is related to this. According to her,

You are born with rhythm [...] your heart beats so when that heart is going through disharmony you have a heart attack and we have all kinds of physical problems. So we go through a rhythm cycle in life also. That's a very natural phenomenon; when that is lost somehow things go wrong. Well, dance has helped them bring that harmony back. (28 May 2010)

There are days when she does not teach anything at all, but simply talks about her experiences, which become storytelling sessions. Improvising her "classes" flexibly and maintaining open-endedness offers a freedom from the monotony of doing things within a framework of routine-rule-bound rationality. Roy asserts,

I also do that with my regular classes most of the times because I don't want dance to be a thing they have to do, they have to complete. I have not done it and I don't think I want my students to go through that monotony, whether it's outside or inside. [...] That helps them to enjoy. And when you enjoy, anybody feels good-that itself works as a therapy—I feel. [...] You see, I feel dance itself is a therapy. There are [...] counsellors who go and counsel them. [...] Maybe they don't really understand their needs or [pause] see although they are like you and me-normal human beings. But being there it changes your own mindset. As a result they have to be dealt with in a very different way. And, nothing works better than love and compassion. (2 June 2010)

Again, her perception of the incarcerated as "normal," her acceptance of them as persons like "you and me," is the foundation of her intervention. The authenticity of emotions plays a critical role here as most of the prisoners are hyper-sensitive. She points out, "it's actually that true feeling that matters. They can all see through any facade, let me tell you, none of them is a fool" (4 November 2010). Her own personality, endowed with artistic sensibilities, seems clearly indispensible for such a relationship, though she does not mention it herself. Dancing with the prisoners meant that at each step she had to improvise through a situation never experienced before and yet involving people, who, she believed, were "just like us" inside.

Initially, the male prisoners had reservations about dancing, as they felt that dance was something girlish. When they were assured that they were going to do manly dances, their numbers increased from ten to sixty. None knew anything about dance other than maybe a little bit of improvised "break dance." Roy introduced Kalaripayatu (a martial art form originating in Kerala) and Thangta (a Manipuri martial art form) accompanied by the drum. She said she hardly thought then that they would be performing on stage one day. Movements from African dances and other tribal dances that they could do easily were also included. They thoroughly enjoyed the folk dance form, with its catchy tunes and rhythm, despite practicing a variety of other styles, including baul, Rabindranritya, dandiya, and 
bhangra. Ingold and Hallam's observations regarding the relational dimension of improvisation echo Roy's practices and pedagogy. According to them,

Improvisation is relational [...] because it goes on along "ways of life" that are as entangled and mutually responsive as are the paths of pedestrians on the street. And by the same token, the creativity it manifests is not distributed among all the individuals of a society as an agency that each is supposed to possess a priori [...] but rather lies in the dynamic potential of an entire field of relationships to bring forth the persons situated in it. (Hallam and Ingold 7)

Roy ascribes the gradual development of a feeling of belonging and solidarity to the folk form, which is danced mostly in groups. Moving together to the rhythm has forged discipline, team spirit, and compassion among them. A form has thus emerged, as Leroi-Gourhan would point out, from participating in the rhythmic gestures together within a flexible framework which accepts "not-doing anything": a form of relationality that opened up a new path to the participant's self-perception, uncovering an identity hitherto unknown or unlived in. Such creative participation helps the prison inmates relax and open-up, which facilitates verbal self-expression and interactions with her and others. While one can view this as a kind of counselling, Roy maintains, "I listen to each and every one of them individually [...] I don't use the word 'counselling,' [...] it's just a one-to-one feeling” (4 November 2010).

None of this is "done" in the sense of pre-planned activity. From the very beginning the whole process unfolded spontaneously. The decisions made in the spur of the moment were carried out with conviction, genuine feelings, and camaraderie. She reiterated,

I was always a dancer and I dance thinking that it is the therapy of the soul without trying to apply it. I have never applied it as a therapy on them. Everything happened. [...] My instrument has been dance. [...] It's the feelings that counts, whether it's music, or sports or painting-whatever. I am talking about the art form because that's what I am comfortable with. You can do it in so many ways. (4 November 2010)

Clearly from her experience, a certain direct connection becomes central to such improvisation as she lived out. Roy's improvisational approach differs significantly from that of Peters. Peters argues against the role of dialogue and empathy within improvisatory practice:
By shifting attention away from the communicative communion that can emerge within the now of an improvised performance towards instead the silent (or silenced) origin of the artwork outside of or "alongside" [...] the intersubjective world, the emphasis throughout is on mounting a resistance to all dialogics that would reduce improvisation to a glorified love-in dressed-up as art. In short, the fundamental relationship is here understood to be between improvisor and improvisation, not between improvisor and improvisor. [...] this is not an awareness of the other but of the inevitable situatedness of the improvisor in a work, the contingency of that work, and of the agility necessary to avoid becoming trapped in the communicative community created by it. (3)

Roy, on the other hand, asserts the importance of commencing with genuine feelings which, in her view, cuts through the rock. Her ensured presence is central to the improvisatory practices as she works with persons, most of whom have shut themselves out of "inner grace" with their conviction and imprisonment.

\section{Skill, Improvisation, Performance: The Way of the Gods Opens out into Us}

The first dance production within the jail was titled "Brotherhood beyond Boundaries." A wandering baul travels all over India and joins dancers from the north, south, east, and west in martial and folk dances. He attains liberation in realizing that boundaries are senseless and that violence and evil serve no purpose. After it was performed before the public at the Uday Shankar Dance Festival in 2007 and was much lauded, ${ }^{8}$ Roy and Sharma selected "Valmiki Pratibha" for the prison inmates to perform next.

The story tells of a dreaded dacoit, Ratnakar, who asks his men to catch a suitable sacrificial animal to propitiate the goddess of destruction, Kali, before going on a plunder. They bring back a small girl who is lost in the forest. Raising his sabre to behead her, Ratnakar finds his hands trembling as her innocent pleas for mercy fill the dark depths of the forest. Once he releases her, his men desert him, thinking he has lost his power to lead them. He too is amazed at his change of heart and roams alone in the forest. One day he encounters a group of hunters taking aim at a pair of mating swans. After they shoot one down, despite his vehement protestations, a divine couplet of wisdom escapes Ratnakar's lips. Amazed at how the "language of the Gods" could flow through his tongue, he glimpses the Goddess 
of Wisdom, Saraswati, without knowing who she is. Then, the Goddess of Wealth appears before him and tempts him with material prosperity. However, Ratnakar respectfully declines, for he now wants to surrender himself to the dawnlike Saraswati, attired in pure white. His devotion and renouncement are rewarded as the Goddess appears before him and blesses him with eternal creative wisdom and her veena. ${ }^{9}$ He becomes the sage Valmiki, the creator of the epic poem Ramayana.

Around mid 2008, the singing and dance workshops began in the Presidency Correctional Home. Exquisite costumes and stage props were made by the prisoners. Some of the prison staff and even their family members were involved in the rehearsals. This being their second public performance, the level of scepticism was much less. Only Akkara, who was designated to play the part of the protagonist, expressed some doubts about being able to pull off a performance of the stature of Tagore's Valmiki. Sharma reminisces,

Six months later on November 15 at 6.30 p.m. at the packed Science City Auditorium and on December 15 at the same time in Rabindra Sadan, Kolkata, it was the moment of truth. Two nights of performance! There was much excitement for the forty-five men and thirteen women inmates, who being accorded the treatment of performing artists, were visibly overwhelmed with the experience. At that moment, in the anticipation and excitement of performing before a live audience, they seemed to have, at least for that moment, transcended their sense of being prisoners. As they scurried around putting on make-up and costumes in the green room, they were like any other performing artist, just concentrated on the moment and the performance ahead of them. What ensued in the next two hours was something to witness. The audience was spellbound; first, by the sheer brilliance of the production. ${ }^{10}$ Everything from the song and dance sequences, the dialogues and action to the sets, props and costumes, seemed to be the work of professionals. It was hard to imagine that the performers were amateurs [...] that too inmates who were lodged in jails. Second, the audience was witnessing history. For the first time perhaps in the history of prisons in the world, jail staff were performing along with prisoners in the same play. The Deputy Jailor Mandira Panja and four staff namely Ranjit Chowdhury, Gopal Sarkar, Shibu Majumdar and Prabir Halder from the correctional homes participated in the dance drama. [...] Roy herself took part in the production, as [...] Goddess Saraswati. [...] there were some interesting role reversals with prison staff, normally the custodians of law inside the prisons, playing the parts of the dissenting dacoits. For the prisoners, who were performing, it was truly a journey from darkness to light. Many of them had tears in their eyes. (16 November 2010)

Sharma himself sang the songs for Valmiki. In this way, almost the entire prison community was involved in the process. Between 2008 and the present, they have staged more than fifty performances of the dance drama within the state and across India. The prisoners have performed in central universities, Indian Institutes of Technology, famous metropolitan auditoriums, and suburban towns. Special shows have been arranged for Supreme Court Judges and other bureaucratic functionaries. Sharma has travelled with prisoners for performances across West Bengal and India, with nominal police escort and sometimes without. In all this time, not a single prisoner has attempted to escape.

Initially, the police in the other states of India, like Delhi and Mumbai, were wary of the team and would install a large retinue to escort them to the city auditoriums. But after seeing the performance and having interacted with the prisoner-performers, they relaxed. The public have been very appreciative and supportive everywhere that Sharma has taken his team to perform. The initial reactions of surprise from elite audiences in cities as well as roadside teastall owners and tourists on the beach at Puri, Orissa, to name a few, have always given way to appreciation.

After Tasher Desh, the inmates of Berhampore Correctional Home (BCCH) also performed on a number of other Tagorean pieces. Sharma opines that this exposure to Tagore's creations has shown spectacular results:

The remarkable changes in their personalities were beyond imagination. Exposure to culture and a sense of dignity and self-respect awakened in them by the standing ovation and public appreciation worked as therapy. I, therefore, gave it the name Culture Therapy. In the coming three years more celebrities joined the culture therapy movement and a number of other disciplines were added to the programme, which included music, recitation, art, painting, and sculpture. And of course public performances in all those different disciplines by prisoners. The Prisoners were taken out of the prisons, on parole, to the exhibitions of paintings and sculptures made by them to elucidate their artworks to the viewers. ${ }^{11}$ In fact, there have been 89 such performances by the prisoners so far. These went off incident-free and without any trouble whatsoever. (Sharma 6) 
As discussed before, the subjects of the dance dramas reflect a reality close to the members of the prison community. Ingold and Hallam observe, "every idea is like a place you visit. You may arrive there along one or several paths, and linger for a while before moving on, perhaps to circle around and return some time later. Each time you revisit the idea it is a little different, enriched by the memories and experience of your previous stay" (8).

Rehearsing the "conflicts" (as Shaw would have it) and acting out their complexes ${ }^{12}$ have brought the inmates in contact with classical thinkers and artists who have grappled with the same paradoxes. Improvising their way through such self reflective content, the inmates walk a path, "carrying"13 the tradition of classical art performance forward; "they linger for a while" on the ideas that these generate "before moving on" to playing them, embodying them for a certain time-the rehearsal span and then the time on stage. Practicing for hours together, improvising to each other's gestures, aligning movements with Roy's and each other's, and bringing it all closer and closer to the "perfect" that none has seen yet but knows somehow-improvisation is the thread that runs through the fabric of movementskill-performance. Speaking in Ingold's terms, this becomes a journey where they see new lands with people living in different ways, perhaps themselves, taking roads not known or less travelled. The perspective generated, the skill acquired through mastering "extra-daily practices," 14 and the act of performing proficiently to large audiences yield the sense that life no longer remains the same. In the words of Nigel Akkara, an ex-inmate and beneficiary of the process, "I was kept locked twenty-four hours. Very rarely they used to take me out because I had cases of hitting the cops; [...] I was very violent. So for the next three months they kept me in police custody and for those 90 days they beat me like anything." Showing his fingers and hands he says:

All my fingers were broken, my legs were broken; they broke everything, but not even a drop of tear fell. And neither did they get anything, it didn't affect me.

One day the superintendent called me and told, "We need some young people within the age group of 20 to 35 to learn dance." I told him, "you have gone off your head; you think that you are going to make goondas ${ }^{15}$ dance?" [...] He said, "it's a martial dance"; I got interested. I went, I saw Mrs. Roy, she was teaching dance and along with her she had her team. I used to stand behind all of them and watch, I never used to dance. Then one day I went up to her (the devil was disturbing me from inside), and told her, "see you are like my mother, you are as old as my mother, do me a favour, remove me from this dance." Then she said, "you don't want to dance there is no problem, you stand behind and watch." I used to do that.

Then one day the IG [Inspector General] came, I was searching for an opportunity to run away from there, so I went up to him and told him that I am having lot of problems. He asked, "What are your problems?" The first thing is that I know that they will not keep me in a ward where the counting is too much, so I told him that I don't want to stay in that dancer's ward, you keep me in the convict ward, where the counting was about 250-300. He said, "OK you go and stay in that ward. What else?" "I need medical diet." He said "OK I shall give you medical diet" [...] he solved all my problems. And then he told me, but you have to dance. So I had no way out. I could not argue or fight with him. So again I used to stand behind and watch and little movements I used to do [...] It went on for some time, we never knew that there was going to be a programme or anything of that sort, and then suddenly one day they decided that in jail they will do a programme. So I performed in that programme and then I had written a speech and I spoke to the people that day. The first time in my life I spoke [to an audience], I was shivering. Then suddenly I heard that there is going to be a programme held outside for the Uday Shankar Nritya Utsav.

Before Valmiki [Pratibha] started, she [Roy] selected me as the main character and whatever the story-that story had been a part of my life [...] from Gitabitan (a collection of songs written by Tagore); she read out and she explained the verses to me. The day she explained it was raining and I was not being able to hold myself, at that moment it really felt that there is nobody, all my friends left me, everyone left me (like the dacoit-comrades had left their chief Ratnakar when he refused to sacrifice the little girl) so then I said that I am coming in one minute and I went and got wet in the rain just to make sure that nobody understands that I am crying. After the Valmiki [Pratibha] when I see movie also I feel like crying, now that has become a thing. From within even a smallest mistake I cannot dream of doing now. It's been 11 months I am out [of prison]. (31 May 2010)

Akkara seems to have come a long way. He is able to be moved emotionally by art and can find his place through reflection in the timeless literature. He is no longer one who would nonchalantly suffer police brutality. At the present time, apart from running his own business of employing ex-prisoners as security and cleaning personnel, he volunteers in a number of social work projects and acts in films. 


\section{"For life goes not backwards nor tarries with yesterday" (Gibran 20)}

The inmates' performances generate income, a part of which is channelled into the Prisoners' Welfare Fund. Close to 20 lakhs have been generated during the last three years, which are spent on the education of prisoners themselves, the disbursement of scholarships to their children, financial assistance to prisoners for their daughters' weddings, their own rehabilitation upon their release, and various other welfare programmes. Along with the Fund, Sharma instituted the practice of "reward parole" by which each performing inmate is given five days of parole to visit her or his family without police protection-an administrative step again unheard of perhaps in the entire country. To this date, no prisoner has attempted to escape. According to Sharma, informal systems of communication are in place to handle possible deviant behaviour if and when it arises. These are steps in administrative reform, though the fact that the rules have not yet been passed by the government remains a point of contention. Reform involves improvisatory acts since a definite form is reached only via trying out various options. Improvisation connotes a beginning while reform necessarily predicates itself upon the existence of something that needs to be changed. And yet such analytical distinction, reflected etymologically, fails to convey that which one experiences in the field: seeing things happen, steps being taken, ways taking shape amidst cuts, cancellations, and rejections. I feel both the notions of improvisation and reform(ulation) share analogous terms with failure, certitude and doubt, being generated from and generative of these, as both are played out in people's actions. Improvising and re-formulating means, rules, and ways of doing things reflect an everyday as well as periodical reality of existence since survival is on-going, and so is growth. This reminds one again of how individual subjectivity is separable from the trajectory of institutions only analytically, not in real terms.

The institutionalization of the Self-Help Fund, ${ }^{17}$ reward parole, and performance opportunities, as well as Roy's artistic interventions, have created a respectable platform for the prisoners to earn social adulation through honest effort, which is significantly helping them to improvise their selfhoods and reform their lives. Living this new identity, even if only for the time being, has changed their outlook. Roy points out, "if I had only focussed on teaching dance movement, I don't think anything like this would have happened. It's always that personal touch and how each one is different from the other. [...] It is a question of being one of them; making them feel that you are there for them, not only dance wise, but even otherwise" (4 November 2010). Both improvisation and reform as realities of human life are linked to questions of social change. Roy's praxis in treating the inmates, invoking the true spirit of human rights, has had a relational effect in socially generating community bonding through creative activity. The effected structural reforms provide them with the opportunity to perform as artists and receive social appreciation for their actions-the sense of achievement and connection with the world outside is thus established. Regarding the perceived change in them, Roy sums up,

changing in the sense that they are going back to their childhood. They are like children, you know. [...] It is not just the action, it is all from within; they feel good. I keep telling them this is freedom of spirit. [...] I would like them to be free as they would be a blessing to the society because they would not betray anybody. I can say this with confidence and conviction. (4 November 2010)

By "like children," she means they are as free and secure with each other and the prison community as children are carefree. When seen in the context of the therapy programme, this atmosphere indicates a change in the environment of the institution. In a similar vein, Hallam and Ingold expand upon Ingold's previous work to examine the implications for the imagination in the creativity of social life:
"social life is not something the person does but rather what the person undergoes" - a process in which people "do not make societies but, living socially, make themselves" (Ingold 1986: 247). Another way of saying that people make themselves is to say that they not only grow but are also grown, in that they undergo histories of development and maturation within fields of relationships established through the presence and activities of others (Ingold 2000: 144). Critically, this growth is not just in strength and stature, but also in knowledge, in the work of the imagination and the formation of ideas. The latter is, after all, as much a full-bodied knitting together of materials and experience as the former. (8)

Roy's account of the effect of the Culture Therapy programme on the prison community is reflective of this process. Underscoring the change in the attitude of the law-keepers as well as the inmates, Roy says:

You know, we have been performing in Rabindra Sadan; about ten or twelve times we have been there. Now, officers keep changing [...] now it's just a formality. They even don't look at that side. Sometimes my boys, if there is a new officer, [...] they will tell them- "Sir there's the gate there also, so guard it." [Laughs] [...] Where will they run away? They say, "Ma, from what? Will we ever be able to survive if we try to 
escape? We won't. We will still be on the run all the time. But here we are getting so much love and respect." (4 November 2010)

On the other hand, these artistic and institutional interventions have triggered social change. Civilians have very rigid ideas of and attitude towards those incarcerated in jails. They range from fear, distrust, and hatred to ignorance and nonchalance. These performances, by their sheer brilliance, have generated fresh public interest in this sphere. Members of audiences repeatedly come backstage after performances to congratulate the inmate-performers. A

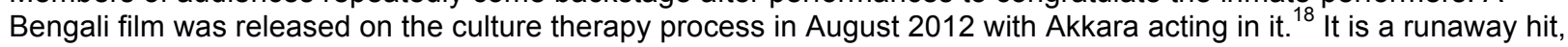
making him an overnight poster boy with a huge Facebook following.

\section{Conclusion}

Interpreting all that one witnessed in the field is a challenging task, as most social phenomena are amenable to multiple lines of interpretation. One can see both ends of a binary in events that are always more than our understanding of them. ${ }^{19}$ Representing field data through ethnographic accounts is itself an improvisational practice. According to Malkki, "in anthropology, as long as it has been a recognizable discipline, there has been a tradition of improvisation. [...] Improvisation is the tradition" (180). One wonders which should enrich the account: that which felt true then and is contained in the field diary, or that which feels truer now, in hindsight. Is opting for both a wiser decision? In the present context, documenting the so-called disappointments, pressures, and obligations would go some way towards providing contours.

As mentioned in his first quote in this paper, despite the public success of the culture therapy programme, B.D. Sharma was transferred to a peripheral department in the police force, following a political regime change in West Bengal in mid 2011. Subsequently, he resigned from the West Bengal state services and is now a senior functionary (Special Director-General, Eastern Zone) of the Border Security Forces (a paramilitary body under the Central Government guarding the political borders of India). Six months before this, he had completed drafting the rules after trying out different modules for improved administration and prison life. Around December 2010, these were submitted to the state government for approval. However, the rules had not been passed by the end of May 2013.

Though none of the institutional changes that Sharma introduced have been misused and the majority of prisoners participating in the culture therapy modules have benefitted, there have been some who could not be rehabilitated. A case in point is that of Barui, whose paintings had been exhibited as part of the art therapy programme. He was released on bail in 2010 but had to be arrested a year later due to his involvement in a robbery. ${ }^{20}$ Instances of tension and disagreements have also surfaced at times. Some of the participant inmates have been removed from the programme on disciplinary grounds. However, such occasions are sparse, and the overall success of prisoner rehabilitation is consistent. Akkara has become involved in the process, recruiting a number of ex-inmates in his company, who now work as cleaning and security personnel.

Working as closely as she does with prisoners, Roy faces pressures that, though she mentions them only in passing, are not hard to imagine. Her effort requires emotional consistency and a certain degree of regular presence among the prisoners. There have been common incidents in the past when some of the prisoners refused to eat because she was absent from the sessions for a few days in the height of summer. Kolkata summer temperature peaks around 40 degrees Celsius, not an advisable temperature for being in the open rehearsal hall at Roy's age. Family members of those imprisoned and attending her "classes" often call her up to enquire about the inmate or pass on an urgent message. However, she does not elaborate on these in her response apart from her acceptance of such situations.

In Max Weber's typology of legitimate domination, members of the bureaucracy would fall within the ambit of legal authority whose basis of being obeyed lay in their holding of office in the rational-legal structure of the bureaucracy and the formal legality of their commands within its scope. B.D Sharma was part of the police bureaucracy and his authority was subject to rational-legal rules of office, not popularity among his subordinates. Yet in his efforts towards giving a solid footing to the culture therapy programme, Sharma strode on unchartered territory. Sharma's active infrastructural facilitation is the key to the "West Bengal Correctional Services Act, 1992" being implemented as per the spirit of its inception. The kind of engagement that he had was not obligatory for him in the context of keeping his job. Sharma repeatedly improvised his way out of bureaucratic status-quo-ism while still remaining well within the constitutional framework. He thus wielded his legal authority of office to enhance the well-being of his subordinates, apart from fulfilling the administrative function for which he held office. In the process, he gained the trust of the inmates to the extent that they return on time after their paroles without police surveillance. 
The improvisory social practices of the artist-activists challenge the instituted physical and emotional separation between prisoners and non-prisoners in quite practical, considered ways. Both Sharma and Roy, in their respective fields of activity, have dealt with failure-systemic and personal-by holding on to the felt certitude of the artist's truth (Roy's belief that all can dance and feel good; Sharma's faith that the quality of the inmates' performance would be appreciated by the general public, the trust bestowed on those performing would be honoured by them, etc.). Their intervention has generated doubt in the social sphere, questioning the rigid stereotype that all prisoners have antisocial, pathological personalities, permanently. They have also created opportunities for the inmates to cope with past failure by fostering a sense of wellbeing. The risks taken have generated change in the institutional ways of interaction within the Correctional Homes. The prison staff is currently receiving training for working within this changed institutional context that the rehabilitative legislation and improvisatory implementation set in motion. The system has thus been altered and updated, generating fresh conditions for further negotiation as life goes on.

\section{Notes}

${ }^{1}$ All respondents spoke in English for the interviews, which were digitally recorded. Since English is a foreign language for both the interviewer and interviewees, the grammatical syntax of the responses was not of textbook perfection. However, for reasons of authenticity the exact textual reproduction of the recorded version has been maintained.

${ }^{2}$ The em-dash (-) signifies the speaker leaving the former thought of his or her sentence in mid speech.

${ }^{3}$ Incidentally, Tagore could not adjust to the prevalent education system. He opted out of school, as well as college, and was educated privately.

${ }^{4}$ Roy is trained in two classical Indian dance forms, music, and Russian Ballet. Her performance career spans fifty years. She has widely experimented with dance drama by bringing together pure classical dance form and technique with contemporary expression and style in choreography, presentation, and costume.

${ }^{5}$ Parole applies to the conditional release of a prisoner temporarily for a special purpose before the expiry of a sentence on the promise of good behaviour.

${ }^{6}$ For more information, see Soutik Biswas's "India's prison theatre gives hope" press-release for the BBC from 13 December 2006: http://news.bbc.co.uk/2/hi/south_asia/6220406.stm.

${ }^{7}$ One of Kolkata's best-known auditoriums.

${ }^{8}$ For more information on the festivities, see Shyamhari Chakra's "A befitting tribute to a legend" from The Hindu, 28 December 2007: http://www.hindu.com/fr/2007/12/28/stories/2007122850610200.htm.

${ }^{9} \mathrm{~A}$ veena is a stringed musical instrument.

${ }^{10}$ For reviews and coverage of the production, please see the following press releases: "Valmiki Pratibha sets a landmark" from The Times of India, 31 October 2012, (http://articles.timesofindia.indiatimes.com/2012-10-

31/kolkata/34836681_1_culture-therapy-inmates-prisons); "When life imitates art" from The Hindu, 5 November 2012, (http://www.thehindu.com/news/cities/Delhi/when-life-imitates-art/article4062109.ece); Falguni Banerjee's "Kolkata jail inmates to tell tale of reform" from The Times of India, 25 September 2011,

(http://articles.timesofindia.indiatimes.com/2011-09-25/mumbai/30200185_1_jail-inmates-presidency-jail-dancedrama); Soudhriti Bhabini's "Jailbirds stage drama on robber's reform" from overseas indian, 23 February 2012, (http://overseasindian.in/2010/feb/news/20102302-105915.shtml); and Pragya Paramita's “Tagore's Valmiki comes alive on stage in prisoners' play" from The Indian Express, 16 March 2009,

(http://www.indianexpress.com/news/tagore-s-valmiki-comes-alive-on-stage-in-prisoners--play/434964).

${ }^{11}$ For further information please see the press release "Liberation through art" from The Telegraph, 16 October 2008 : http://www.telegraphindia.com/1081016/jsp/calcutta/story_9971414.jsp.

${ }^{12}$ A complex is a collection of various ideas held together by an emotional tone common to all (Jung 599). 
13 "Following a tradition [...] is a matter not of replicating a fixed pattern of behaviour, but of carrying on from predecessors" (Hallam and Ingold 7).

${ }^{14}$ Extra-daily practices are those practices such as rituals, dances, theatre performances, the recitation of oral narratives, meditation and/or religious practices, martial arts, etc., which require the practitioner to undergo specialized body training in order to become accomplished in attaining a certain specialized state of consciousness, body, agency, power, and so on (Zarrilli 5).

${ }^{15}$ Bengali for "hoodlums."

${ }^{16}$ A special diet that includes animal protein dishes.

${ }^{17}$ For more information, please see Debashis Konar's "Inmates raise Rs 2.5 lakh for prisoner welfare fund" from The Times of India, 16 November 2008: http://articles.timesofindia.indiatimes.com/2008-11-

16/kolkata/27900875_1_prisons-department-women-inmates-state-jails-department.

${ }^{18}$ Please see the following press releases for more information: Rina Mukherji's "When criminals dance to the tunes of a dancer-social worker" from The Weekend Leader, 17 September 2010,

(http://www.theweekendleader.com/Culture/249/making-of-valmikis.html); Chandreyee Chatterjee's "Dance therapy to help quit crime addiction" from The Telegraph, 9 July 2011,

(http://www.telegraphindia.com/1110709/jsp/calcutta/story_14214492.jsp); Anupam Mukerji's “A Convinct's Escape" from Open, 30 October 2010, (http://www.openthemagazine.com/article/true-life/a-convict-s-escape); Jhimli Mukherjee Pandey's "Gangster's take-II on life makes it to silver screen" from The Times of India, 2 October 2012, (http://articles.timesofindia.indiatimes.com/2012-08-02/kolkata/33000077_1_silver-screen-transformation-indiandance); Monideepa Banerjie's "'Muktadhara': Seeking a second chance” from NDTV, 3 August 2012, (http://www.ndtv.com/article/cities/muktadhara-seeking-a-second-chance-251064); Arghya Ganguly's "Road to redemption" from Business Standard, 8 October 2011, (http://www.business-standard.com/article/beyondbusiness/road-to-redemption-111100800021_1.html); HP Wire's "Nigel Akkara: A criminal turned actor" from Hill Post, 26 August 2012, (http://hillpost.in/2012/08/nigel-akkara-a-criminal-turned-actor/49694/); "Gangster to Hero" from Savvy (http://www.magnamags.com/newM/savvy/index.php?option=com_content\&view=article\&id=45\&ltemid=48); S.N.M. Abdi's "Lines from Balmiki" from Outlook India, 13 August 2012, (http://www.outlookindia.com/printarticle.aspx?281826); Pradipta Tapadar's "When an Indian dancer reformed a hardened criminal" from India Africa Connect (http://www.indiaafricaconnect.in/index.php?param=news/4859/panorama/115); and Priya Sreekumar's "From jail to the big screen" from Deccan Chronicle, 5 January 2013, (http://www.deccanchronicle.com/130105/entertainmentmollywood/article/jail-big-screen).

19 "For the world will not be closed, and goes its own way regardless of what we may say about it" (Hallam and Ingold 15).

${ }^{20}$ Some relevant press-releases on this topic include: "Convicted of killing kin, Sajal Barui attempts suicide in jail" from The Indian Express, 5 April 2010, (http://www.indianexpress.com/news/convicted-of-killing-kin-sajal-baruiattempts-suicide-in-jail/600078/1); "17 years after triple murder, Sajal walks 'out' of jail” from The Indian Express, 11 August 2010, (http://www.indianexpress.com/news/17-years-after-triple-murder-sajal-walks--out--of-jail/658839/1); and "Sajal Barui arrested in robbery case" from The Times of India, 28 June 2011, (http://articles.timesofindia.indiatimes.com/2011-06-28/kolkata/29712640_1_guest-house-sajal-barui-rony).

\section{Works Cited}

Akkara, Nigel. Personal Interview. 31 May 2010.

Bergson, Henri. An Introduction to Metaphysics. Trans. T.E. Hulme. Indianapolis: Hackett Publishing Company, 1999. Print.

Douglas, Anne and Kathleen Coessens. "Experiential Knowledge and Improvisation: Variations on movement, motion, emotion." Art, Design, and Communication in Higher Education 10.2 (2012): 179-89. Print. 
Douglas, Anne and Kathleen Coessens. "Improvisation and Experimentation in Everyday Life and Beyond." Sourcebook on Experimentation in Art. Leuven: $U$ of Leuven P, 2014. Forthcoming.

Gibran, Kahlil. The Prophet. London: Heinemann, 1973. Print.

Hallam, Elizabeth and Tim Ingold. "Creativity and Cultural Improvsiation: An Introduction." Creativity and Cultural Improvisation. Eds. Elizabeth Hallam and Tim Ingold. Oxford: Berg, 2007. 1-24. Print.

Ingold, Tim. Section Introduction. Creativity and Cultural Improvisation. Eds. Elizabeth Hallam and Tim Ingold. Oxford: Berg, 2007. 45-54. Print.

Jung, Carl Gustav. "On the Doctrine of Complexes." Collected Works. Princeton: Princeton UP, 1973. 598-604. Print.

Leroi-Gourhan, André. Gesture and Speech. Cambridge, Mass: MIT Press, 1993. Print.

Malkki, Liisa H. "Tradition and Improvisation in Ethnographic Field Research." Improvising Theory: Process and Temporality in Ethnographic Fieldwork. Eds. Allaine Cerwonka and Liisa H. Malkki. Chicago: U of Chicago P, 2007. 162-87. Print.

Metamorphosis. Dir. Abhijit Das Gupta. Kolkata Sukriti Foundation, 2009. Film.

Peters, Gary. The Philosophy of Improvisation. Chicago: U of Chicago P, 2009. Print.

Roy, Alokananda. Personal Interview. 28 May 2010.

---. Personal Interview. 2 June 2010.

---. Personal Interview. 4 November 2010.

Sharma, B.D. Personal Interview. 16 November 2010.

---. Personal Interview. 17 November 2010.

---. Personal Interview. 27 August 2012.

---. "Prison and Ethics: The West Bengal Experiment." 2011. TS. 1-12.

Weber, Max. Economy and Society, Vol. 2. Berkeley: U of California P, 1978. Print.

West Bengal. Home Department. "West Bengal Correctional Services Act, 1992." The West Bengal Jail Code, Vol. 1. Calcutta: Home Department, Government of West Bengal, India, 2000. 489-566. Print.

---. "West Bengal Jail Rules." The West Bengal Jail Code, Vol. 1. Calcutta: Home Department, Government of West Bengal, India, 1967. 1-439. Print.

Zarrilli, Phillip. When the Body Becomes All Eyes: Paradigms, Discourses and Practices of Power in Kalarippayattu, a South Indian Martial Art. Delhi: Oxford UP, 1998. Print. 